\title{
Foreign Aid and Economic Development in Sub-Saharan Africa: The Mediating Role of Governance Effectiveness
}

\author{
Richard Ilorah \\ University of Limpopo, South Africa \\ richard.ilorah@gmail.com \\ Collins C. Ngwakwe \\ University of Limpopo, South Africa \\ collins.ngwakwe@ul.ac.za
}

This paper aims to analyse the effect of foreign aid, moderated by governance effectiveness variables, on economic development in sub-Saharan Africa. Data on foreign aid, GDP and governance variables were from the World Bank governance archives covering five sub-Saharan African countries. The paper applied the oLs and fixed effect panel multiple regression analysis. From the first analysis, findings show a negative link between external aid and GDP per capita in sub-Saharan Africa. In the second analysis with governance moderating variables, findings indicate a positive relationship between foreign aid and GDP with rule of law providing a positive boost to foreign aid and GDP growth, but corruption and governance have a negative relationship with economic growth. The paper highlights policy implications for the need to bridle corruption and to strengthen governance institutions to enable foreign aid to function effectively toward economic growth. The paper suggests an agenda for further research to apply more governance institution variables in further analysis of aid effectiveness in sub-Saharan Africa economic growth.

Key Words: foreign aid, economic development, governance institutions, poverty JEL Classification: M2, O1

(c) BY-SA https://doi.org/10.26493/1854-6935.19.307-326

\section{Introduction}

The role of foreign aid in managing the development of transition economies continues to be contentious and non-conclusive in global transitions literature. It is important to recognise that how the government applies the foreign aid to local investment does matter in boosting the effectiveness of foreign aid. This is why Ioan and Ioan (2016) highlight the im- 
portance of clear direction and quality of investment in promoting economic growth. In addition, well-functioning economic institutions are very important in directing the course of economic growth (Žižmond and Novak 2006). Africa's prevalent reliance on external aid has largely provoked a well-being mindset in the continent (Easterly 2002). Aid to sub-Saharan Africa (s A) remains significant: during 2005-2013, the region received about 88 percent of the U $\$ 416.9$ billion in official aid to the African continent (OECD 2014). Earlier, during 1980-2004, the continent received U $\$ 716.15$ billion in official aid, with over 65 percent of that total allocated to ss A (Lal and Rajapatirana 2007).

However, some researches argue that in some instances, the benefit of aid to recipient countries does not reflect on the pace of economic growth. For instance, some researches express the negative sentiment that aid to some countries has rather encouraged poor accountability and deeper dependence, and promoted dysfunctional institutions (Grabowski 2006). However, it does seem that aid-led economic growth has not been noticeable for sub-Saharan Africa. Hence, critics of aid question the effectiveness of aid to reduce poverty and promote development, especially in the absence of selectivity in aid allocation (Bhagwati 2010). Therefore, aid and economic development within sub-Saharan Africa remain a conundrum, which requires unceasing research inquiry and solutions, especially considering that sub-Saharan Africa is a region lagging behind in global transition (UNDP 2021). It presents a unique analysis wherein the aid and development nexus is conducted first and then the governance mediating variables are included in a second analysis.

Research on external aid and development in Africa has had variegated results (Mallik 2008). Some researchers find a significant link between external aid and economic growth (Adebayo and Beton Kalmaz 2020). Others find a negative link between aid and economic growth (Ismail 2020). Yet others insist that foreign aid relates to economic development in sub-Saharan Africa (Mbah and Amassoma 2014). However, many researchers have overlooked that the government bureaucrats are in charge of overseeing the application of foreign aid in local investments. Hence, the effectiveness of governance should be brought into the analysis of whether foreign aid does promote economic growth in sub-Saharan Africa. This paper contributes by controlling the foreign variable with government institution variables (namely corruption control, rule of law and government effectiveness) in examining the influence of foreign aid on economic growth in sub-Saharan Africa. 
TABLE 1 Sub-Saharan Africa Foreign Aid (FAid) Received, and GDP per Capita

\begin{tabular}{lrrrrrrr}
\hline Year & $(1)$ & $(2)$ & & Year & $(1)$ & $(2)$ \\
\cline { 1 - 2 } 2000 & 3.42 & $1,227.74$ & & 2010 & 3.36 & $1,592.59$ \\
2001 & 3.92 & $1,246.97$ & 2011 & 3.20 & $1,620.10$ \\
2002 & 4.80 & $1,291.81$ & 2012 & 2.98 & $1,641.14$ \\
2003 & 5.01 & $1,311.73$ & 2013 & 2.86 & $1,677.76$ \\
2004 & 4.28 & $1,360.29$ & 2014 & 2.66 & $1,711.91$ \\
2005 & 4.48 & $1,404.48$ & 2015 & 2.77 & $1,712.18$ \\
2006 & 4.67 & $1,453.91$ & 2016 & 2.95 & $1,685.68$ \\
2007 & 3.57 & $1,506.95$ & 2017 & 3.12 & $1,683.09$ \\
2008 & 3.48 & $1,545.13$ & 2018 & 3.04 & $1,681.38$ \\
2009 & 3.97 & $1,550.24$ & 2019 & 3.23 & $1,675.68$ \\
\hline
\end{tabular}

NOTES Column headings are as follows: (1) foreign aid (percentage of GNI), (2) GDP per capita (constant 2010 U s\$). Based on data from World Bank (see https://datacatalog .worldbank.org).

The rationale and hence the need for this paper intertwines around the problem of lack of significant economic growth and the high rate of poverty in sub-Saharan Africa. Despite many years of aid dependency (table 1), sub-Saharan Africa has little pragmatic evidence of aid-led economic growth. Yet the region accounts for the highest aid dependency ratio, more than other regions of the world, and whereas it is expected that aid in sub-Saharan would engender growth for poverty reduction, this has not matured as desired. Sub-Saharan Africa continues to account for the lowest economic growth and highest level of poverty amongst the world's regions; hence, global transition to sustainable development by 2030 appears elusive in this region of the world. Therefore, this paper is important as it contributes toward efforts to find solutions to the problem of lack of aid effectiveness on growth - in this instance, this paper focuses on how governance effectiveness variables might mar or improve aid effectiveness. This paper's focus on sub-Saharan Africa is unique because the region is trailing behind in the race for sustained growth and development, and is still in dire need of solutions to lift the region out of its economic and social woes. Hence, research papers such as this are most pertinent to provide empirical suggestions that may contribute in lifting the region to a better trajectory of economic growth and development.

Table 1 shows the foreign aid (official development assistance $=$ ODA as $\%$ of GNI) received into sub-Saharan Africa and the sub-Saharan African 


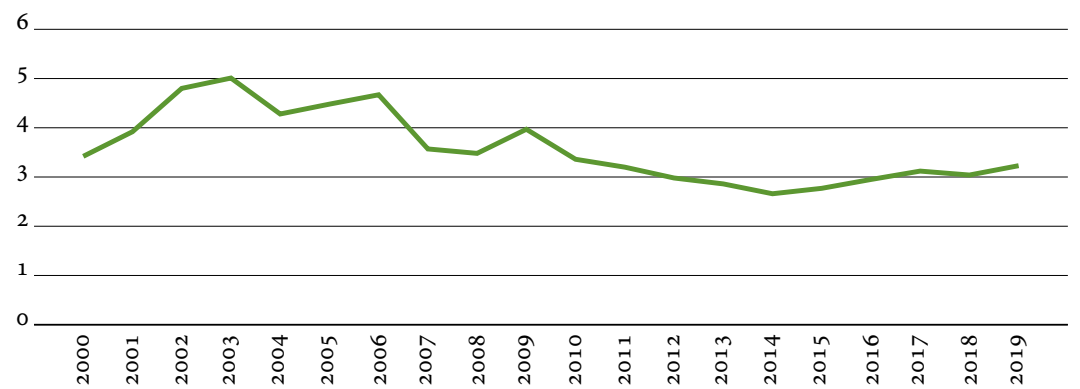

FIGURE 1 Sub-Saharan Africa Foreign Aid Received (Percentage of GNI)

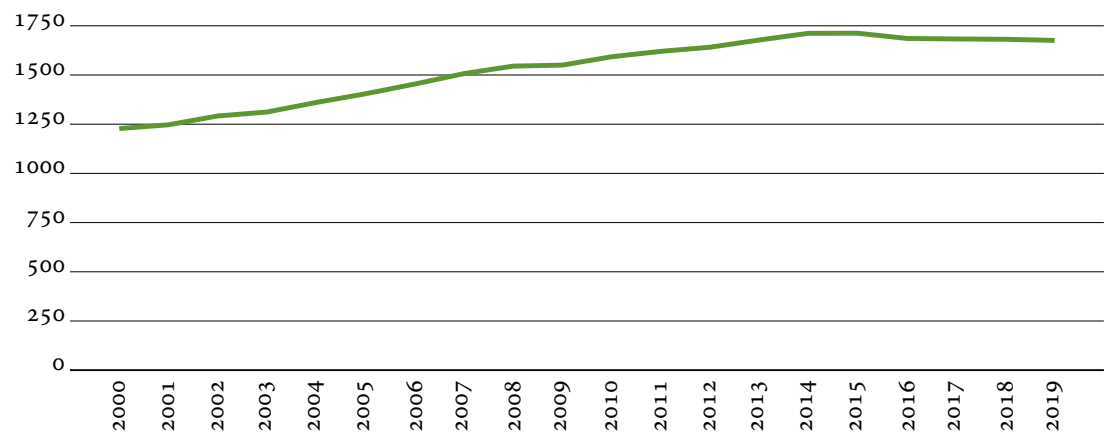

FIgURE 2 Sub-Saharan Africa GDP per Capita (Constant 2010 US\$)

economic growth (GDP per capita) for twenty years (2000-2019). Figures 1 and 2 show the line trend of foreign aid (ODA) received (as percentage of GNI) and GDP per capita for sub-Saharan Africa for twenty years.

The problem of this paper pivots on weak economic growth and development in sub-Saharan Africa amidst aid receipt over the years. Much blame has often been ascribed to the international obstacles to growth with little attention on national institutional problems such as corruption, which some researchers bemoan as a factor that weakens governance effectiveness toward economic policies and hence weakens the rule of law. By extension, institutional economics theorists attribute weak institutions in sub-Saharan Africa as debilitating foreign aid's influence on growth. However, these institutional variables such as corruption, rule of law, and governance effectiveness, have barely been subjected to empirical test along with foreign aid within the region to evaluate how a combination of the variables may influence economic growth. This current paper aspires to this unique analysis.

Accordingly, the objective of this paper is to analyse the influence of 
foreign aid, moderated by government effectiveness variables (corruption, rule of law and governance effectiveness), on economic development in sub-Saharan Africa. It aims to first ascertain if foreign aid has a positive or negative relationship to sub-Saharan Africa economic development (Omoteso and Mobolaji 2014). Therefore, this paper rests on a fundamental research question, namely how does foreign aid influence economic development in sub-Saharan Africa when moderated by government effectiveness variables.

\section{Literature Review}

Minoiu and Reddy (2010) studied the impact of official development assistance on the growth of developing economies. They applied a different approach from previous research by separating aid meant for development and aid specifically targeted at development. Their analysis also provides a basis for further research to conduct a long-term evaluation of the effect of aid on growth. Their findings show that the developmental type of aid has a significant influence on the enhancement of longterm economic growth in developing countries. They also postulate that donors prioritise their donation to enhance development and productive relationships with the recipients and thirdly that some donors shelve excessive strategic bottlenecks to promote political institutions that prioritise development policies.

Other researchers argue and find empirically that this is not often the case, that in some instances, aid has not occasioned the desired economic development (Rajan and Subramanian 2008; Minoiu and Reddy 2010). In addition, they cite Kilby and Dreher (2010) to argue and provide a caution that it is not always the case that the recipient characteristics invalidate the effectiveness of aid. Rather, the motive behind the donor and the disbursement attributes may have an important effect on how the aid affects development - a character quite separate from the quality of the recipient (Kilby and Dreher 2010).

Contrary to the earlier findings, Das and Sethi (2019) evaluate the impact of external direct investment, official development assistance, and remittances on the economic development of Sri Lanka and India. They applied time series analysis for both countries from 1980 to 2016 and considered both short-term and long-term impacts of the external aid on development. Their findings show that foreign direct investment combined with remittances stimulates economic growth in India. However, for Sri Lanka, economic growth derives from the combination of foreign aid and 
remittance inflow to the country. Following the ongoing research and the diverse findings, Azam and Feng (2021) conduct a research wherein they evaluate the effect of external aid on the economic growth of transition countries. They applied a cross-sectional time series technique by using the fixed-effect regression, and analysed up to thirty-seven countries in transition. They kept the countries in blocks of income categorisation, namely upper middle-income, lower-middle income, and low-income. Their statistics results show two different results - firstly they find that a combination of all the income groups with foreign aid produces a positive influence on the economic growth of these countries. However, when they examined the relationship based on the income blocks, results indicate a mixed outcome that resembles an earlier result by Rajan and Subramanian (2008). They find that foreign aid has limited effect on the low-income countries, the lower-middle income countries experience a positive effect of foreign aid and FDI on economic growth, and the upper middle-income countries experience a positive effect on growth from foreign direct investment; however, results for this income group show no positive relationship with economic growth (Azam and Feng 2021).

Researchers also note that countries with endowed natural resources more easily entice inflow of foreign capital (Africa Institute of South Africa 2009), explaining the presence of foreign investors in conflict countries such as Angola, DRC, Chad, Sudan, and Nigeria, even at the peak of conflicts. Development economists worry that, in some instances, a disproportionate amount of profits accrues to foreign investors in the region, implying more capital outflows than inflows. Critics argue that skewed profit-sharing arrangements result in a deficit for some rich countries (Baxter 2002). There is also the problem that foreign aid may at times make the recipient countries perennially dependent on foreign aid. The aid dependency ratios for sub-Saharan Africa, no matter the methods of measurement, are generally much higher than other world regions (World Bank 2006). The ratios are expected to grow even further as the region's population may likely increase by 2030 (Mills 2011). Attempts by poor countries to extricate themselves from poverty are rendered futile because of their entrenched underdevelopment and poor utilization of productive resources; poverty in these countries therefore reinforces and exacerbates a cycle of dependence on aid (Carruth and Freeman 2021; Cleaver 2005). This is why Ioan and Ioan (2016) argue that investment activity must have clearly outlined direction and attention to good infrastructure to have a meaningful effect on economic growth. It therefore 
means that the recipient country has a role to play to make foreign aid influence economic growth. Hence, the following sections provide analysis of how foreign aid influences economic development in sub-Saharan Africa by mediating foreign aid with governance effectiveness variables.

Further research on the aid and growth nexus provides further results using the Cambodian sample between 1980 and 2014. Sothan (2018) applied the auto-regression distributed lag method and included trade liberalisation and investment in the model. He finds that trade liberalisation has a short- and long-term positive influence on growth, and foreign aid shows only a positive effect on economic growth within the short-term period whilst investment shows a positive long-term influence on economic growth. Further results show that in the long-term, foreign aid showed a negative influence on economic growth and investment within the sample studied. He concludes that within the country and sample of study, it is deleterious on growth to depend on foreign aid for a longer period.

Some empirical researches have specifically focussed on examining the effect of aid on the growth of economies and governance in transition countries (Askarov and Doucouliagos 2015a; Cungu and Swinnen 2003; Askarov and Doucouliagos 2015b; Heckelman 2010). Askarov and Doucouliagos (2015a) examined the extent to which aid helps to facilitate economic growth and development in developing economies. Their results show, amongst others, that aid facilitates economic growth within the sample of countries studied. They also find that the results were robust regarding the study sample, the regression estimation, and instrumental control of endogeneity. However, they also find that the efficiency of aid does not necessarily rely on good economic policy.

In another related research, Cungu and Swinnen (2003) applied econometric analysis to examine the impact of aid on economic output and economic growth using a panel sample of countries in transition. Their econometric analysis discovers the existence of a significant and positive relationship between economic growth and receipt of foreign aid. Their further analysis indicates that the economic growth effect of aid is more pronounced under liberal economic conditions - this finding helps to quell the doubtful view of some research and is reassurance that aid can assist in the growth of developing countries.

Another group of researchers has evaluated the role of aid in strengthening governance institutions in developing countries (Askarov and Doucouliagos 2015b). Their finding does show that aid to developing 
countries helps in restoring democracies, especially regarding freedom to exercise political rights. However, although aid enhances democracy, they find no evidence that aid guarantees governance quality; instead, aid from some countries such as the USA produces an apparent negative effect on certain aspects of governance.

Another research by Heckelman (2010) evaluated the effect of aid on democracies in Eastern European countries in transition with various findings, which includes that increase in per capita aid assists in democratic reforms, and improved governance, judiciary, and election processes. Accordingly, this current research applies some governance factors as mediating variables to analyse the effect of foreign aid on economic growth of sub-Saharan African countries. In recognition of the potential influence of institutions in channelling foreign aid toward desired outcome, Babalola and Shittu (2020) evaluated the role played by institutions regarding the relationship between economic development and external aid in recipient countries of West Africa. They applied a panel and autoregressive distribution lag analysis. Within the sample of data, their result shows that external aid has no effect on economic growth of the recipient countries. In addition, when they imputed institutional variables into the equation, the institutional variables changed the outcome to a negative result. This change shows the devastating effect that institutions in sub-Saharan Africa can have on external aid received into the region for development.

Other recent empirical findings include the existence of a short- and long-term relationship between foreign aid and economic growth in subSaharan Africa (Jena and Sethi 2019a). Foreign aid has a negative effect on growth in South and South East Asia (Rao et al. 2020). Foreign aid causally affects economic growth in South Asia (Jena and Sethi 2021), and a long-term relationship exists between foreign aid inflows and economic growth (Sethi et al. 2019a). Furthermore, there is an equilibrium relationship between foreign aid and economic growth in the long- and short-term (Sethi et al. 2019b); inward remittance from abroad has a negative effect on expert growth (Jena and Sethi 2019b).

This paper finds support in the institutional theory of economic development, which raises the sentiment that even with the abundance of material and financial resources, a well-functioning institution is an important recipe for ensuring effective utilisation of resources to the benefit of economic growth (Ferreira, Fernandes, and Ratten 2019). Hence, the institutional theorists see institutions as forces that reign above individu- 
als to either thwart or lend support as a driver of political action that often blends with cognitive ethos to control material resources and systems. In this milieu, since institutions exert influence on policy issues and attendant political actions, it follows naturally that institutions catalyse access to and influence over resources (Wang, Li, and Zhao 2018). Importantly, given their supremacy, political institutions create conditions that may elevate or act as limitations to the extent to which organised groups in the society may successfully mobilize collective goods from the state institution (Amenta and Ramsey 2010). Accordingly, institutions constitute an important arm of economic growth and development given their overriding influence on the freeness of the market system, their enforcement of rights and protection of private property, which contributes to attracting international aid and investment (Chang 2011).

Accordingly, this paper differs slightly from the existing research by measuring the influence of foreign aid on sub-Saharan African economic growth by adding a nuance absent in the literature, which is moderating the influence of foreign aid on growth with three institutional variables, namely rule of law, control of corruption and governance effectiveness. Hence this paper extends existing research. The following sections present the method and results.

\section{Data and Methodology}

The paper applies the fixed effect panel multiple regression model to assess the effect of foreign aid on the economic growth of select sub-Saharan African countries. The proxy for economic growth is the GDP per capita and the proxy for foreign aid is the net official development assistance (ODA). Previous researchers on economic development have highlighted the importance of good government, such as corruption control, rule of law and effective government, in a positive economic growth (Aluko and Ibrahim 2020; De Vaal and Ebben 2011). However, previous researches have not integrated a model of foreign aid with government variables to assess GDP per capita growth. Therefore, this paper makes a novel contribution by employing government variables as a control to see how government effectiveness may support the aid received in the enhancement of economic growth. This becomes necessary because the government manages the foreign aid received.

Data on foreign aid (which is ODA as proxy), GDP per capita, and government effectiveness were derived from the World Bank archive of economic indicators and World Bank Governance Indicators respectively. 
In the main analysis of this research, data cover a sample of five subSaharan African countries over a period of four years, which constituted the panel data arrangement. The five sub-Saharan African countries are Ghana, Guinea, Gambia, Guinea-Bissau, and Equatorial Guinea.

Previous researchers have also applied fixed effect regression and panel data in economic growth research (Van Eyden et al. 2019; Gozgor, Lau, and $\mathrm{Lu}$ 2018). This paper contributes to existing models by incorporating both the foreign aid variable and government performance variables (government effectiveness, rule of law, and control of corruption) in gauging aid effectiveness on economic growth in sub-Saharan African countries. Another novelty in this research approach is that firstly, before engaging in the main analysis, the first analysis provides empirical confirmation of the research problem, which is that foreign aid to sub-Saharan Africa appears not to support positive economic development in subSaharan Africa. Equation 1 is the model for this first analysis, and the result appears in table 2.

The regression equations for the analysis appear below.

First analysis:

$$
Y=\beta_{\mathrm{o}}+\beta_{1} \chi_{1}+\varepsilon,
$$

where $Y$ is economic development (represented by GDP per capita), $\beta_{\mathrm{O}}$ is intercept or constant, $\beta_{1}$ is gradient or regression coefficient, $\chi_{1}$ is foreign aid (shortened as FAid in the analysis), and $\varepsilon$ is error (other independent variables unaccounted for in the model).

Second analysis:

$$
Y=\beta_{\mathrm{o}}+\beta_{1} \chi_{1}+\beta_{2} \chi_{2}+\beta_{3} \chi_{3}+\beta_{4} \chi_{4}+\varepsilon,
$$

where $Y$ is economic development (represented by GDP per capita), $\beta_{\mathrm{o}}$ is intercept or constant, $\beta_{1}-\beta_{4}$ are gradient or regression coefficients, $\chi_{1}$ is foreign aid (represented by FAid in the analysis), $\chi_{2}$ is governance effectiveness (represented by GovEffect in the analysis), $\chi_{3}$ is corruption control (represented by CorControl in the analysis), $\chi_{4}$ is rule of law (represented by RuleofLaw in the analysis), and $\varepsilon$ is error (other independent variables unaccounted for in the model).

\section{Definition and Measurement of Variables$$
Y-G D P \text { per Capita }
$$

GDP per capita is measured by dividing the GDP by the midyear population of a country (see https://datacatalog.worldbank.org). It is calculated in constant 2010 US\$. 


\section{$\chi_{1}-$ Foreign Aid}

Foreign aid denotes the international process of moving of money, goods or services from developed countries or international institutions to developing countries, meant for improving the welfare of the receiving country's citizens (Corporate Finance Institute 2021). This paper uses a popular foreign aid proxy referred to as Official development assistance (ODA) (OECD 2021). 'Official development assistance (ODA) is defined by the OECD Development Assistance Committee (DAC) as government aid that promotes and specifically targets the economic development and welfare of developing countries' - according to OECD, the 'DAC adopted ODA as the "gold standard" of foreign aid in 1969 and it remains the main source of financing for development aid' (OECD 2021). ODA is measured by multiplying the annual disbursement on loans to developing countries by the loan's grant component, which is calculated during the time of loan commitment (OECD 2021). Therefore, the World Bank derives a percentage of ODA from the gross national income (GNI) for each country, and this paper uses the ODA as a percentage of GNI as calculated and documented in the World Bank development data archives (see https://data.worldbank.org/indicator/DT.ODA.ALLD.CD).

\section{$\chi_{2}-$ Governance Effectiveness}

Governance effectiveness refers to a country's public service quality, the extent to which public service is free from political pressure to thwart policy and service offerings, formulation of policies, and the credibility thereof. The World Bank measures governance effectiveness using percentile ranking amongst all countries, ranging from o (lowest) to 100 (highest). Accordingly, this paper used the World Bank's measured data on governance effectiveness (see https://datacatalog.worldbank.org).

\section{$\chi_{3}$ - Corruption Control}

Corruption control level refers to the level to which public office holders use public power to pursue private advantages and/or gains. The World Bank measures corruption control using percentile ranking amongst all countries, ranging from o (lowest) to 100 (highest).

$$
\chi_{4} \text { - Rule of Law }
$$

A country's rule of law refers to the extent to which various agents adhere to and exercise confidence in the county's rules guiding the society. It goes 
TABLE 2 OLS, Using Observations 2000-2019 $(T=20)$

\begin{tabular}{lcccr}
\hline Variable & Coeff. & Std. error & $t$-ratio & $p$-value \\
\hline Const. & 2178.66 & 124.385 & 17.5154 & $<0.00001^{* * *}$ \\
FAid & -181.029 & 34.0134 & -5.3223 & $0.00005^{* * *}$ \\
\hline Mean dependent variable & 1529.038 & SD dependent variable & 167.2776 \\
Sum squared resid. & 206570.3 & SE of regression & 107.1267 \\
$R$-squared & 0.611457 & Adj. $R$-squared & 0.589872 \\
$F(1,18)$ & 28.32695 & P-value(F) & 0.000046 \\
Log-likelihood & -120.8054 & Akaike criterion & 245.6108 \\
Schwarz criterion & 247.6023 & Hannan-Quinn & 245.9996 \\
Rho & 0.451875 & Durbin-Watson & 0.560183 \\
\hline
\end{tabular}

Notes Dependent variable: GDP per Capita ssA.

further to include the credibility of business contract enforcement, credibility of law enforcement agents and the credibility of the court for seeking redress and obtaining equitable justice irrespective of social and economic status. The World Bank measures rule of law effectiveness using percentile ranking amongst all countries, ranging from o (lowest) to 100 (highest). Accordingly, this paper used the World Bank's measured data on governance effectiveness (see https://datacatalog.worldbank.org).

\section{Empirical Results and Findings}

As indicated in the above models in equation 1 and equation 2, the analysis is in two phases. The first analysis tries to appraise whether foreign aid influences economic growth in sub-Saharan Africa. The second analysis uses equation 2 to show how the introduction of governance variables assists foreign aid effectiveness for five select sub-Saharan African countries.

Table 2 shows that the relationship is significant at a $P$-value of 0.00005 . However, the relationship is negative with a coefficient of -181.029 . This shows that within the period of study, foreign aid in sub-Saharan Africa has a negative relationship with economic growth. The negative relationship in this finding, which uses the whole of sub-Saharan African foreign aid and GDP per capita data, confirms the prior findings of a negative or no relationship between foreign aid and economic growth (Adebayo and Beton Kalmaz 2020; Babalola and Shittu 2020).

This first analysis and result provide the impetus to progress to the next 
TABLE 3 Summary Statistics

\begin{tabular}{lrrrr}
\hline Variable & Mean & Median & Minimum & Maximum \\
\hline RuleofLaw & 23.0590 & 9.26000 & 4.23000 & 60.5800 \\
CorControl & 21.9325 & 13.8450 & 0.00000 & 58.2500 \\
GovEffect & 21.3655 & 15.1100 & 1.94000 & 57.7700 \\
FAid & $4.19152 e^{8}$ & $1.30640 e^{8}$ & $7.49000 e^{6}$ & $1.80387 e^{9}$ \\
GDP PCapt_Cnst & 3686.98 & 799.628 & 539.511 & 18261.1 \\
\hline Variable & Std. Dev. & C.V. & Skewness & Ex. kurtosis \\
\hline RuleofLaw & 21.2146 & 0.920015 & 0.677130 & -1.27347 \\
CorControl & 20.9349 & 0.954515 & 0.649221 & -1.11757 \\
GovEffect & 17.2773 & 0.808656 & 0.806539 & -0.564212 \\
FAid & $5.60865 e^{8}$ & 1.33809 & 1.59800 & 1.22525 \\
GDP PCapt_Cnst & 5942.06 & 1.61163 & 1.73183 & 1.28427 \\
\hline
\end{tabular}

analysis that uses data from a sample of five countries in sub-Saharan Africa to reassess the relationship between foreign aid and economic growth with the introduction of governance effectiveness variables as control variables on foreign aid. Table 3 and table 4 present the descriptive statistics and correlation coefficient.

Although table 3 is not of use in the variables relational analysis discussed, suffice it to say the core interest in table 3 is the mean, which shows the mean occurrence of each variable and the coefficient of variation, which shows the degree of dispersion during the period. Foreign aid has the highest mean occurrence during the period, followed by the GDP, rule of law, corruption, and governance effectiveness, respectively. In terms of coefficient of variation (Cv), GDP registered the highest level of dispersion during the period; this is followed by foreign aid, rule of law, corruption, and governance effectiveness, respectively. These are only descriptive characteristics of the variables and have no direct implication on the regression results discussed.

Fixed effect panel regression appears in table 5 and shows that the direction of the relationship between foreign aid and GDP per capita changes to a positive sign after the introduction of three governance variables (rule of law, corruption, and governance effectiveness) into the model.

Results from this second analysis show that when foreign aid is moderated with the three governance variables, foreign aid is positively re- 
TABLE 4 Correlation Coefficients

\begin{tabular}{lrrrrr}
\hline Variable & $(1)$ & $(2)$ & $(3)$ & $(4)$ & $(5)$ \\
\hline (1) RuleofLaw & -0.3204 & 0.6338 & 0.6316 & 0.6511 & 1.0000 \\
(2) CorControl & -0.4400 & 0.6861 & 0.6677 & 1.0000 & \\
(3) GovEffect & -0.4377 & 0.6159 & 1.0000 & & \\
(4) FAid & -0.2953 & 1.0000 & & & \\
(5) GDP & 1.0000 & & & & \\
PCAPT_CNST & & & & & \\
\hline
\end{tabular}

TABLE 5 Panel Data Regression Result for Foreign Aid and GDP in a Sample of Five Sub-Saharan African Countries

\begin{tabular}{lrrrr}
\hline Variable & Coeff. & Std. Error & $t$-ratio & $p$-value \\
\hline Const. & 2832.750 & 3034.490 & 0.9335 & 0.37059 \\
RuleofLaw & 98.177 & 127.339 & 0.7710 & 0.04569 \\
CorControl & -120.012 & 116.266 & -1.0322 & 0.02413 \\
GovEffect & -179.593 & 111.045 & -1.6173 & 0.03410 \\
FAid & 0.039 & 0.0246 & 0.1572 & 0.04779 \\
\hline$R$-squared & 0.939496 & & & \\
Adj. $R$-squared & 0.895492 & & & \\
Durbin-Watson & 2.000112 & & & \\
$P$-value $(F)$ & 0.000012 & & & \\
\hline
\end{tabular}

NOTES Model 1: Fixed-effects, using 20 observations. Included: 5 cross-sectional units. Time-series length $=4$. Dependent variable: GDP Per Capita.

lated to economic growth at a significance level of $P=0.0024$, which is far below the alpha level of 0.05. However, worthy of note is that it does seem that rule of law provides a positive significant booster to the positive influence of foreign aid on economic growth, as it has a positive regression coefficient of 98.1775 and a significant $p$-value of 0.04 . However, it is concerning that corruption and governance effectiveness have a negative effect on economic growth with negative regression coefficients of -120.012 , and -179.593, and significant $p$-values of 0.02 and 0.03 , respectively. This result also shows that weak control of corruption and weak governance have a negative relationship with economic growth, and this shows that weak governance and a low rate of corruption control can impair economic growth even in the presence of foreign aid. This second result is consistent with earlier findings, which indicate that under cer- 
TABLE 6 Robust and Diagnostic Test Summary

\begin{tabular}{ll}
\hline $\begin{array}{l}\text { Hausman Model Selection for } \\
\text { Random or Fixed Effect Test }\end{array}$ & $\begin{array}{l}P \text {-value }=0.0011 \text { (therefore, random effect model is } \\
\text { not suitable) }\end{array}$ \\
$\begin{array}{ll}\text { Correlation coefficients } \\
\text { The correlation matrix table indicates no multi- } \\
\text { collinearity }\end{array}$ \\
Adjusted $R$-squared & 0.939 \\
Autocorrelation & 0.895 \\
Dormality of residual & $=2.001$, which indicates no autocorrelation \\
& $\begin{array}{l}\text { The errors are normally distributed with a } p \text {-value }= \\
0.4010 \\
\text { The White's test for heteroskedasticity indicates there }\end{array}$ \\
& is no heteroskedasticity at a $P$-value = 0.1022
\end{tabular}

tain circumstances, foreign aid can have a positive effect on economic growth (Das and Sethi 2019; Minoiu and Reddy, 2010).

In order to conclude results arising from regression results, it is important to check how strong the linear relationship is (diagnostic test) (Shi 2013). In addition, it is also very vital to check how accurate the testing method is (robust test) (Aveh and Awunyo-Vitor 2017). This paper conducted a robust and diagnostic analysis (table 6) to improve the credibility of the results.

The Hausman Test: For random and fixed effect, suitability was conducted to determine the most appropriate model of panel regression to enhance methodological robustness. The null hypothesis is: random effect is suitable; and the alternative hypothesis: fixed effect is suitable. Since the $P$-value is $=0.0011$, the null hypothesis of random effect suitability was rejected (therefore, random effect is not appropriate). Hence, fixed effect is used. In addition, table 4 presents the correlation matrix table and indicates absence of multicollinearity. Furthermore, the diagnostic tests for the strength of the regression were conducted; the most acknowledged measure of strength of relationship in the literature is the standard error (SE) of regression (Misra, Zimba, and Gasparyan 2021; Walter 2002), which experts also refer to as standard error of estimate. The small standard error of this test being 0.024 suggests that predicted variable lies very close to the regression line - which is a reliable test of regression precision. This is confirmed by the further diagnostics of $R$-squared at $93 \%$ and adjusted $R$-squared at $89 \%$; the Durbin-Watson test of autocorrelation is at a value of $=2.0001$ showing absence of autocorrelation. In 
addition, the normality test and heteroscedasticity tests values of 0.4010 and 0.102 indicate that errors are normally distributed and that there is no heteroskedasticity.

\section{Conclusion and Policy Implication}

This paper aimed to analyse the effect of foreign aid on economic development in sub-Saharan Africa. Prior researchers have dwelt more on exogenous variables, but this paper contributes differently by adding a new model, which integrates endogenous variables, namely the government effectiveness variables as control variables to the foreign aid variable. The analyses were in two separate phases; from the first analysis, findings show a negative link between external aid and economic growth represented by GDP per capita in sub-Saharan Africa. A second analysis, which applied the panel fixed effect multiple regression approach, indicates that indeed, foreign aid does have a positive and significant effect on economic growth. However, this positive relationship showed up after the inclusion of governance variables, namely rule of law, corruption, and governance effectiveness into the equation as intervening variables. In the second analysis, findings indicate that the rule of law provides a positive boost to foreign aid and GDP growth. In contrast, an increasing level of corruption and weakening governance showed a negative relationship with economic growth. This finding corroborates previous findings on the positive relationship between foreign aid and growth (such as Das and Sethi 2019; Minoiu and Reddy 2010). However, the difference between this paper's findings and previous findings is that foreign aid became positively significant only when governance variables were added - thus adding a nuance to this paper and signifying the importance of institutional or governance variables in boosting aid effectiveness in sub-Saharan Africa. Hence, this second result indicates an important policy implication on the need to bridle corruption and strengthen the rule of law and government effectiveness institutions to enable foreign aid to yield the dividend of economic growth in sub-Saharan Africa.

Relying on the findings, the paper recommends the need for economic policy makers to improve the state institutional control mechanisms to reduce the level of corruption in the governance sector as one of the strategic economic growth policy measures. This is because bureaucrats are in charge of and provide policies and operations for investing the proceeds of foreign aid, and this needs to be done in an effective and accountable manner. Another recommendation for economic policy mak- 
ers' attention is the dire need for strengthening the rule of law and government effectiveness as this research shows that weakness in the rule of law and government effectiveness has the propensity to retard the positive effect of foreign aid on economic growth. Furthermore, the existing subregional trade blocs in the region need strengthening to promote effective use of the region's natural resources to promote economic growth with the assistance of foreign aid. Therefore, economic policy makers should also consider effective apparatus to turn the weakening trajectory of government effectiveness toward a positive trajectory.

The limitation of this paper lies in its focus on data from sub-Saharan Africa and on limited time coverage, mainly due to availability of data for the sample. However, this limitation is an opportunity for further research to explore this important growth and development concept further. Accordingly, the paper provides an avenue for future researchers to extend this research more by conducting regional analysis that may use data from western, southern, and eastern African countries to assess how regional variables might affect the result of the aid's effect on economic growth. In addition, such future research should strive to include all governance variables, which may reveal more results on additional governance variables that have the propensity to assist foreign aid to grow or retard economic growth.

\section{References}

Adebayo, T. S., and D. Beton Kalmaz. 2020. 'Ongoing Debate between Foreign Aid and Economic Growth in Nigeria: A Wavelet Analysis.' Social Science Quarterly 101 (5): 2032-51.

Africa Institute of South Africa. 2009. Africa at a Glance: Facts and Figures 2008-2009. Pretoria: Africa Institute of South Africa.

Aluko, O. A., and M. Ibrahim. 2020. 'Institutions and the Financial Development-Economic Growth Nexus in Sub-Saharan Africa.' Economic Notes 49 (3): e12163. https://doi.org/10.1111/ecno.12163.

Amenta, E., and K. M. Ramsey. 2010. 'Institutional Theory'. In Handbook of Politics: State and Society in Global Perspective, edited by K. T. Leicht and J. C. Jenkins, 15-39. New York: Springer.

Askarov, Z., and H. Doucouliagos. 2015a. 'Development Aid and Growth in Transition Countries.' World Development 66:383-99.

- 2015b. 'Aid and Institutions in Transition Economies.' European Journal of Political Economy 38:55-70.

Aveh, F. K., and D. Awunyo-Vitor. 2017. 'Firm-Specific Determinants of Stock Prices in an Emerging Capital Market: Evidence from Ghana 
Stock Exchange.' Cogent Economics \& Finance 5 (1). https://www.doi.org /10.1080/23322039.2017.1339385.

Azam, M., and Y. Feng. 2021. 'Does Foreign Aid Stimulate Economic Growth in Developing Countries? Further Evidence in Both Aggregate and Disaggregated Samples.' Quality \& Quantity. https://link.springer .com/article/10.1007/s11135-021-01143-5.

Babalola, S., and W. Shittu. 2020. 'Foreign Aid and Economic Growth in West Africa: Examining the Roles of Institutions.' International Economic Journal 34 (3): 534-52.

Baxter, J. 2002. 'Another Africa is Possible.' Africa Recovery 16 (1): 18-9.

Bhagwati, J. N. 2010. 'Banned Aid: Why International Assistance Does Not Alleviate Poverty'. Foreign Affairs 89 (1): 120-5.

Carruth, L., and S. Freeman. 2021. 'Aid or Exploitation? Food-for-Work, Cash-for-Work, and the Production of Beneficiary-Workers in Ethiopia and Haiti.' World Development 140. https://doi.org/10.1016/j .worlddev.2020.105283.

Cleaver, F. 2005. 'The Inequality of Social Capital and the Reproduction of Chronic Poverty.' World Development 33 (6): 893-906.

Chang, H. J. 2011. 'Institutions and Economic Development: Theory, Policy and History'. Journal of Institutional Economics 7 (4): 473-98.

Corporate Finance Institute. 2021. 'Foreign Aid: The Voluntary Movement of Capital from One Country to Another.' https://corporatefinance institute.com/resources/knowledge/economics/foreign-aid/.

Cungu, A., and J. Swinnen. 2003. 'The Impact of Aid on Economic Growth in Transition Economies: An Empirical Study.' Licos Discussion Paper 128, Katholieke Universiteit Leuven, Leuven.

Das, A., and N. Sethi. 2019. 'Effect of Foreign Direct Investment, Remittances, and Foreign Aid on Economic Growth: Evidence from two Emerging South Asian Economies.' Journal of Public Affairs 20. https://onlinelibrary.wiley.com/doi/abs/10.1002/pa.2043.

De Vaal, A., and W. Ebben. 2011. 'Institutions and the Relation between Corruption and Economic Growth.' Review of Development Economics 15 (1): 108-23.

Easterly, W. 2002. The Elusive Quest for Growth: Economists' Adventures and Misadventures in the Tropics. Cambridge, m A: Mi T Press.

Ferreira, J. J., C. Fernandes, and V. Ratten. 2019. 'The Effects of Technology Transfers and Institutional Factors on Economic Growth: Evidence from Europe and Oceania.' The Journal of Technology Transfer 44 (5): 1505-28.

Gozgor, G., C. K. M. Lau, and Z. Lu. 2018. 'Energy Consumption and Economic Growth: New Evidence from the oECD Countries.' Energy 153:27-34. 
Grabowski, R. 2006. 'Political Development, Agriculture, and Ethnic Divisions: An African Perspective.' African Development Review 18 (2): 163-82.

Heckelman, J. C. 2010. 'Aid and Democratization in the Transition Economies.' Kyklos 63 (4): 558-79.

Ioan, C. A., and G. Ioan. 2016. 'An Equilibrium Model for the Romanian Economy' The Journal of Accounting and Management 6 (2): 41-75.

Ismail, K. M. 2020. 'Impact of Foreign Aid on Economic Growth in Tanzania.' Master's dissertation, The University of Dodoma.

Jena, N. R., and N. Sethi. 2019a. 'Foreign Aid and Economic Growth in SubSaharan Africa.' African Journal of Economic and Management Studies 11 (1): 147-68.

- 2019b. 'Does Inward Remittance Lead to Export Performance in South Asian Countries?' International Journal of Social Economics 47 (2): $145-72$.

- 2021. 'Foreign Capital and Growth Nexus Revisited: Empirical Evidence from South Asian Countries. Transnational Corporation Review 13 (3): 269-92.

Kilby, C., and A. Dreher. 2010. 'The Impact of Aid on Growth Revisited: Do Donor Motives Matter?' Economics Letters 107 (3): 338-40.

Lal, D., and S. Rajapatirana. 2007. 'The Triumph of Hope over Experience: A Marshall Plan for Sub-Saharan Africa?' American Enterprise Institute for Public Research 2:1-7.

Mallik, G. 2008. 'Foreign Aid and Economic Growth: A Cointegration Analysis of the Six Poorest African Countries.' Economic Analysis \& Policy 38 (2): 251-6o.

Mbah, S., and D. Amassoma. 2014. 'The Linkage between Foreign Aid and Economic Growth in Nigeria.' International Journal of Economic Practices and Theories 4 (6): 1007-17.

Mills, G. 2011. 'Urban Youth Can Save Africa Or Sink It.' Sunday Times, 9 October.

Minoiu, C., and S. G. Reddy. 2010. 'Development Aid and Economic Growth: A Positive Long-Run Relation.' The Quarterly Review of Economics and Finance 50 (1): 27-39.

Misra, D. P., O. Zimba, and A. Y. Gasparyan. 2021. 'Statistical Data Presentation: A Primer for Rheumatology Researchers.' Rheumatology International 41 (1): 43-55.

OECD. 2014. 'ODA Receipts and Selected Indicators for Developing Countries and Territories.' http://www.oecd.org/dac/stats/ statisticsonresourceflowstodevelopingcountries.htp.

_. 2021. 'Official Development Assistance.' https://data.oecd.org/oda /net-oda.htm. 
Omoteso, K., and H. I. Mobolaji. 2014. 'Corruption, Governance and Economic Growth in Sub-Saharan Africa: A Need for the Prioritisation of Reform Policies.' Social Responsibility Journal 10 (2): 316-30.

Rajan, R. G., and A. Subramanian. 2008. 'Aid and Growth: What Does the Cross-Country Evidence Really Show?' The Review of Economics and Statistics 90 (4): 643-65.

Rao, D. T., N. Sethi, D. P. Dash, and P. Bhujabal, 2020. 'Foreign Aid, FDI and Economic Growth in South-East Asia and South Asia.' Global Business Review. https://doi.org/10.1177/0972150919890957.

Sethi N., P. Bhujabal, A. Das, and S. Sucharita. 2019a. 'Foreign Aid and Growth Nexus: Empirical Evidence from India and Sri Lanka.' Economic Analysis and Policy 64:1-12.

- 2019b. 'Does Foreign Aid Act as an Instrument of Economic Growth in India and Sri Lanka?' Jurnal Ekonomi Malaysia 53 (2): 319.

Shi, Y. 2013. 'A New Diagnostic Test for Regression.' Master thesis, The University of Western Ontario.

Sothan, S. 2018. 'Foreign Aid and Economic Growth: Evidence from Cambodia.' Journal of International Trade \& Economic Development 27 (2): 168-83.

UND P. 2021. Graduation of African Least Developed Countries. https://www .africa.undp.org/content/rba/en/home/library/reports/graduation-ofafrican-least-developed-countries-ldcs-emergin.html.

Van Eyden, R., M. Difeto, R. Gupta, and M. E. Wohar. 2019. 'Oil Price Volatility and Economic Growth: Evidence from Advanced Economies Using More than a Century's Data.' Applied Energy 233:612-21.

Walter, S. D. 2002. 'Properties of the Summary Receiver Operating Characteristic (s roc) Curve for Diagnostic Test Data.' Statistics in Medicine 21 (9): 1237-56.

Wang, S., J. Li, and D. Zhao. 2018. 'Institutional Pressures and Environmental Management Practices: The Moderating Effects of Environmental Commitment and Resource Availability.' Business Strategy and the Environment 27 (1): 52-69.

World Bank. 2006. World Development Indicators 2006. Washington, DC: The World Bank.

Žižmond, E., and M. Novak. 2006. 'Impact of Price-Deregulation on Market Outcomes: The Case of Chimney Sweep Services in Slovenia.' Prague Economic Papers 15 (4): 350-63. 